\title{
ТЕХНОЛОГИИ ИСКУССТВЕННОГО ИНТЕЛЛЕКТА \\ В ПОИСКЕ СИСТЕМНЫХ МУЛЬТИТАРГЕТНЫХ ФАРМАКОЛОГИЧЕСКИ АКТИВНЫХ ВЕЩЕСТВ
}

\author{
П.М. Васильев ${ }^{1,2}$, А.А. Спасов ${ }^{2,1}$, Д.А. Бабков ${ }^{1,2}$, Д.В. Мальцев ${ }^{2,3}$, \\ А.Н. Кочетков
}

\footnotetext{
${ }^{1}$ Научный центр инновационных лекарственных средств, ФГБОУ ВО ВолгГМУ Минздрава

России, 400087, Россия, г. Волгоград, ул. Новороссийская, 39.

${ }^{2}$ Кафедра фармакологии и биоинформатики, ФГБОУ ВО ВолгГМУ Минздрава России, 400001, Россия, г. Волгоград, ул. Ким, д. 20.

ЗЛаборатория экспериментальной фармакологии, ГБУ «Волгоградский медицинский научный центр», 400131, Россия, г. Волгоград, пл. Павших Борцов, д. 1.
}

DOI: 10.19163/MedChemRussia2021-2021-166

E-mail: pvassiliev@mail.ru

Излагаются результаты использования технологии искусственных перцептронных нейронных сетей для построения классификационных консенсусных ансамблевых мультитаргетных моделей, описывающих зависимости трех различных видов системной фармакологической активности - RAGEингибирующей, анксиолитической и предотвращающей гиперцитокинемию, от рассчитанной методом докинга аффинности соединений к релевантным этим активностям белкам-мишеням. Модели включают: 34 ключевых биомишени для RAGE-ингибирующей активности; 14 ключевых биомишеней для анксиолитической активности; 6 ключевых биомишеней для способности снижать гиперцитокинемию. Каждая такая модель состоит из трех ансамблей нейросетей для трех градаций активности (высокая, умеренная, низкая), по семь нейросетей в каждом ансамбле. Прогноз активности соединения выполняется на основе двухуровневого консенсуса. Сначала для каждой градации активности с применением простого консенсуса обобщается спектр семи первичных оценок, полученных при прогнозе с использованием входящих в данный ансамбль нейросетей. При расчете консенсусной оценки второго уровня обобщаются консенсусные оценки первого уровня для трех градаций активности, с одновременной их проверкой на непротиворечивость. Прогностическая точность консенсусных моделей оценивалась на объединенных выборках методом ROC-анализа.

Полученные модели используются для направленного поиска in silico новых системных мультитаргетных веществ с высокой активностью: RAGEингибиторов для лечения осложнений при сахарном диабете и болезни Альцгеймера; анксиолитиков нетрадиционного действия; соединений, предотвращающих развитие гиперцитокинемии при COVID-19.

Исследования выполнены при финансовой поддержке грантов Минобрнауки

России № 075-15-20-777.

$$
-166-
$$

